\title{
Multiple Pregnancy Increases the Risk of Toxoplasma Gondii Infection
}

Priscilla Vilela dos Santos

Universidade Federal de Ouro Preto

Débora Nonato Miranda Toledo

Universidade Federal de Ouro Preto

Bianca Alves Almeida

Universidade Federal de Ouro Preto

Valter $\mathrm{F}$ Andrade-Neto

Universidade Federal do Rio Grande do Norte

Nathalia S Guimarães

Universidade Federal de Ouro Preto

André Talvani ( $\boldsymbol{\nabla}$ talvani@ufop.edu.br)

Universidade Federal de Ouro Preto https://orcid.org/0000-0002-6685-6229

Research

Keywords: multiple gestations, pregnant, congenital toxoplasmosis, risk factors, Women's Health Services

Posted Date: September 14th, 2021

DOI: https://doi.org/10.21203/rs.3.rs-876151/v1

License: (c) (i) This work is licensed under a Creative Commons Attribution 4.0 International License.

Read Full License 


\section{MULTIPLE PREGNANCY INCREASES THE RISK OF TOXOPLASMA GONDII} INFECTION

Priscilla Vilela dos $\operatorname{Santos}^{1,2}$, Débora Nonato Miranda de Toledo ${ }^{1,2}$, Bianca Alves Almeida Machado $^{1,3}$, Valter Ferreira de Andrade-Neto ${ }^{4}$, Nathalia Sernizon Guimarães ${ }^{2}$,

$$
\text { *André Talvani }{ }^{1,2,5}
$$

${ }^{1}$ Laboratório de Imunobiologia da Inflamação, Departamento de Ciências Biológicas/ICEB, Universidade Federal de Ouro Preto, Ouro Preto, MG, Brasil, ${ }^{2}$ Programa de Pós-Graduação em Saúde e Nutrição, Universidade Federal de Ouro Preto, Ouro Preto, MG, Brasil, ${ }^{3}$ Escola de Medicina, Universidade Federal de Ouro Preto, Ouro Preto, MG, Brasil, ${ }^{4}$ Laboratório de Biologia da Malária e Toxoplasmose, Departamento de Microbiologia e Parasitologia, Universidade Federal do Rio Grande do Norte, Natal, RN, Brasil, ${ }^{5}$ Programa de Pós-Graduação em Ciências da Saúde, Infectologia e Medicina Tropical, Universidade Federal de Minas Gerais, Belo Horizonte, MG, Brasil.

Correspondence to:

20 André Talvani; talvani@ufop.edu.br

Departamento de Ciências Biológicas/ICEB, UFOP

and

Nathalia Sernizon Guimarães; nasernizon@gmail.com

Escola de Nutrição, ENUT, UFOP

Campus Morro do Cruzeiro, 35400-000 Ouro Preto, MG, Brazil 


\section{Abstract}

27 Background. Congenital toxoplasmosis (CT) is an infectious disease caused by placental transfer of Toxoplasma gondii protozoa to the fetus, and can generate neurological and neurocognitive deficits, or death. As a mother's infection poses the risk of fetal transmission in about $30 \%$ of the cases, appropriate preventive strategies are required for infection-related risk factors. The present study assessed the prevalence of $T$. gondii infection and the factors associated with congenital toxoplasmosis in pregnant women with assistance from the Public Health Service at Ouro Preto, Brazil. Methods. This cross-sectional study was conducted between April and December 2020. Pregnant women $(n=131)$ aged between 13 and 46 years, were recruited and evaluated for specific $\operatorname{IgM}$ and $\operatorname{IgG}$ antibody levels against $T$. gondii. These women also responded to a structured questionnaire, which was later used to determine the socioeconomic, environmental, gestational, clinical, and dietary patterns. Results. The prevalence of infection by $T$. gondii was $45.8 \%(n=60)$; of these, multigravida women were more exposed to infection and were 2.6 times more likely to become infected with $T$. gondii compared to primigravida women (OR: 2.60; $95 \% \mathrm{CI}: 1.25-5.39$ ). A high prevalence of $T$. gondii seropositivity was identified in pregnant women in the region of Ouro Preto, Brazil, where part of the sample reported the absence of basic sanitation at home. Conclusion. Our data identified multigravida as a potential risk factor for gestational toxoplasmosis, based on the high positivity of anti-T. gondii serology in these women Thus, educational and preventive measures must be intensified in both primigravida and multigravida women, to increase awareness regarding the potential risks of contact with $T$. gondii.

Key words: multiple gestations, pregnant, congenital toxoplasmosis, risk factors, Women's Health Services. 


\section{Introduction}

Congenital toxoplasmosis (CT) is an infectious disease caused by placental transfer of Toxoplasma gondii protozoa to the fetus, and can result in neurological and neurocognitive deficits or death $[1,2]$. Most cases are asymptomatic in immunocompetent individuals, even though some patients may experience self-limiting symptoms such as febrile conditions, lymphadenopathy, hepatosplenomegaly, and eventual skin rash [3, 4]. The pathogenesis of toxoplasmosis varies by strain and host susceptibility based on an individual's genetic traits [5], causing significant damage and even death in immunocompetent adults [6]. In pregnant women, placental transference of the protozoan is related to severe toxoplasmosis in neonates, which may be related to the genetic characteristics of $T$. gondii isolates prevalent in animals and humans [7].

T. gondii infection is predominantly widespread in tropical climates, especially at low altitudes, as the oocysts survive better in these environments [8,9]. It is estimated that approximately $51.4 \%$ of pregnant women worldwide are infected with the parasite [10]. In Brazil, T. gondii infection ranges from $50-80 \%$ in women of reproductive age [11].

Maternal serological screening during prenatal care enables the identification of infected and vulnerable pregnant women for follow-up as a means to reduce the risk of fetal infection [12, 13]. The severity of congenital toxoplasmosis is inversely related to the gestational period at the time of infection. At the beginning of pregnancy, transmission is low, but the pathology can be severe. At the end of pregnancy, high transmission occurs, but with a lower risk of miscarriage [14]. Treatment during pregnancy is related to a lower risk of infection and decreased severity in babies $[15,16]$. Maternal health issues in Brazil have been discussed in 1980, with the implementation of different maternal health policies and programs [17], in addition to greater access to prenatal care in health units [18]. In Italy, Slovenia, France, and Austria, the prenatal program is mandatory, whereas in the United States of America, lack of 
screening has contributed to greater disease severity, which is only observed at birth $[19,20$, 21, 22].

Epidemiological research in urban and rural environments shows geographical territory together with the perception of the disease spread. Thus, detection of risk factors associated with $T$. gondii infection can lead to improvements in preventive health strategies [23, 24]. In this context, the present study aimed to assess the prevalence of $T$. gondii infection and the factors associated with congenital toxoplasmosis in pregnant women with assistance from the Public Health Service at Ouro Preto, Brazil.

\section{Materials and methods}

A cross-sectional study was conducted with pregnant women between April and December 2020, with assistance from the Public Health Service at Ouro Preto, Brazil.

After signing the assent form (for children's parents or responsible girls $<18$ years old) or consent form (for women $\geq 18$ years old), the non-probabilistic sample, by convenience, included 131 pregnant women, regardless of age. After being recruited, specific $\operatorname{IgM}$ and IgG antibody levels against $T$. gondii were determined. The women also responded to a structured questionnaire that was used to obtain information regarding the socioeconomic (age, education, occupation, income, and place of residence), environmental (access to water, sewage network, urban waste collection, contact with domestic animals, animal disposals at home, gardening, use of personal protective equipment (PPE) in gardening, handwashing after using the bathroom), gestational (gestational age, number of pregnancies, neuroocular complications of the firstborn, abortion, eclampsia, body mass index (BMI) pre-gestational and gestational weight gain), clinical (stool parasitological examination, type of protozoan in stool, blood pressure, kidney disease, urine culture, and types of bacteria), and food (consumption of unpasteurized milk, raw vegetables and meat, fruit/vegetable washing process, cross 
contamination in meal preparation, handwashing before food preparation) conditions. Their weight $(\mathrm{kg})$ and height $(\mathrm{cm})$ were recorded using a stadiometer, which was attached to the Welmy® electronic scale.

The income variable was classified based on the Brazilian minimum wage in Reals (R\$), R\$ 1,045.00 (US\$188) [25]. The cutoff point for the education variable was 12 years of study for categorizing women who had studied until high school. The pre-gestational body mass index variable was classified as "not overweight" for BMI $\leq 24.9 \mathrm{~kg} / \mathrm{m}^{2}$ and as "overweight" for BMI $>25.0 \mathrm{~kg} / \mathrm{m}^{2}$. The gestational weight gain variable was classified as shown in Table 1.

Stool samples were collected and sent to the Inflammation Immunobiology Laboratory (LABIIN) for conservation by the addition of mercury, iodine, and formaldehyde (MIF). Subsequently, the samples were sent to the Clinical Analysis Laboratory of the same institution for analysis using the Hoffman, Pons, and Janer method for parasite identification [26].

Microsoft Excel 2013 was used for data storage. Data analysis was performed using Stata (Stata Corp V.13, Texas, USA) [27]. Descriptive analysis included the distribution of frequencies and the absolute numbers of categorical variables. The prevalence of exposure and non-exposure to T. gondii associated with the $95 \%$ confidence interval were estimated for the included population. To verify the relationship between $T$. gondii exposure and the explanatory variables, univariate logistic regression was used, expressed by the odds ratio adjusted for age. The explanatory variables that presented a p-value $<0.20$ in the univariate analysis, were selected for multivariate analysis. The forward data entry method was chosen wherein all variables selected in the univariate analysis were inserted simultaneously in the model and were then removed individually based on the probability of a likelihood-ratio statistic based on conditional parameter estimates, starting from the least significant. The final model included all variables that were statistically associated with outcomes, showing a p-value $\leq 0.05$. The Hosmer-Lemeshow test was used to analyze or adjust the model. 
Results

127

Of the 131 pregnant women evaluated, 59.54\% reported being in their second pregnancy; however, the prevalence of $T$. gondii infection was $45.8 \%(\mathrm{n}=60)$ and in this group, multigravidae seemed to be more likely to be infected with $T$. gondii $(p<0.009)$. The average age of this group of women was $27.3 \pm 6.6$ years. The participants' sociodemographic, gestational, clinical, and nutritional data, as well as BMI distribution are shown in Table 2.

Most of the pregnant women reported that they had completed high school education (58.02\%), had a job (43.56\%), had an income between two and three minimum wages (52.67\%), lived in the urban area of the city $(60.31 \%)$, and had access to basic sanitation such as running water (86.26\%), a sewage network (89.31\%), and urban waste collection $(97.71 \%)$ at their residence. Half of the participants reported having contact with domestic animals (50.38\%). Among the pregnant women, $25.19 \%$ had gardening habits, and of these, $84.85 \%$ did not wear gloves. Further, $51.91 \%$ of the pregnant women reported that they did not wash their hands after bathroom use.

Regarding clinical conditions, most of the women evaluated were normotensive and did not have kidney disease (95.42\%). Parasitological examination of feces showed $14.10 \%$ of positivity, in which $72.73 \%$ presented the Entamoeba coli protozoa. Among the pregnant women who underwent urine culture $(\mathrm{n}=128)$, Escherichia coli was present in $36.36 \%$ of the samples.

Among the evaluated pregnant women, 59.54\% were in their second pregnancy; of these, $96.95 \%$ and had no history of eclampsia, $19.08 \%$ reported having a prior abortion, $6.11 \%$ reported neurological complications in their firstborn child, and 58.02\% were "overweight" before pregnancy. Further, $37.40 \%$ were in the second trimester of the current pregnancy, and the weight inadequacy was $33.59 \%$ of the evaluated sample. 
Regarding the volunteers' eating habits (dietary variables), most of the sample consumed pasteurized milk (89.31\%), raw vegetables (99.24\%), and raw/undercooked meat (67.94\%). Overall, 50.38\% reported the habit of cleaning/washing fruits and vegetables under running water. When investigating cross-contamination, we observed that $75.57 \%$ washed their knives before reusing them. The volunteers reported that they routinely washed their hands before preparing meals $(94.66 \%)$.

The Table 3 demonstrates the odds ratios for women infected with T. gondii. Among all factors, multigravida women were 2.6 times more likely to become infected with $T$. gondii than primigravida women (OR: 2.60; 95\% CI: 1.25-5.39). This result was observed even after adjusting the odds ratio for age.

The variables of access to garbage collection services, gardening habits, use of PPE in gardening, hand washing after using the bathroom, abortion, eclampsia, type of protozoan in the stool, kidney disease, urine culture and presence of bacteria, consumption of unpasteurized milk, consumption of raw vegetables, consumption of raw meat, fruit and vegetable washing process, and cross-contamination during meal preparation did not show any statistically significant differences.

\section{Discussion}

This study was carried out in the Ouro Preto microregion, which is one of the most important historic cities in the central region of Minas Gerais state in Brazil. The economic activities revolve around mineral extraction, metallurgical industry, tourism, and agriculture. Despite increasing tourist and financial activities, this city has precarious water treatment with $75.6 \%$ of the households having adequate sanitation [28] but lack a water treatment system [29].

Regarding the factors associated with $T$. gondii infection, our results showed that multigravida presented as an important risk factor as multigravida women showed a 2.6 times greater risk of 
being infected compared to primigravida women. In contrast, a recent study conducted in Turkey reported that primigravida pregnant women had a significantly higher risk $(P<0.02)$ of infection with the parasite compared to multigravida women [30]. However, in agreement with our result, Onduru \& Aboud, (2021) [31] reported that in the Temeke district, Dar es Salaam, Tanzania, the probability of a pregnant woman giving birth to a child with a toxoplasmosis was 28.5 times higher in multigravida women than in primigravidae. After adjusting for the effect of confusion and association in the multivariate model, the robustness of the multigestation variable increased to 40.89 times more likely for pathology in the child. There is great cultural diversity among studies from different countries and Brazil, as the culture seems to show overprotection vis-à-vis the firstborn, and through the observation and personal reports of pregnant women, the subsequent pregnancies seem to be more "peaceful," with less stress and more experience. Such facts may contribute to less food care and greater exposure to risk factors such as contact with infected soil and untreated water. As biological explanations, we present the following points in our results: greater vulnerability of multigravida women to the parasite probably occurs due to continuous changes in the immunological mechanisms inherent to pregnancy, resulting from immune response suppression (due to the need for tolerance to the fetus) and/or due to hormonal imbalances characteristic of the gestational condition. Further, unfavorable living conditions of the population in underdeveloped countries with less financial acquisition for larger families can result in a greater chance of infection in women, especially during multi-pregnancy, when they are more vulnerable to parasitic infection.

Further, in the study by Berger et al. (2009) [32], a predisposition to T. gondii infection was observed in multigravida French pregnant women from 1995 to 2003, thus consolidating the variable as a risk factor for the signs and symptoms of toxoplasmosis. 
Effective screening programs are essential for implementing public health policies. In our study, we showed $45.8 \%$ positivity for anti-T. gondii $\mathrm{IgG}$, and other studies carried out in different regions of Brazil showed 45\% positivity in the central-west region of Minas Gerais [33], 50.2\% positivity in Mato Grosso do Sul [34], and 59.8\% positivity in Porto Alegre [35]. In contrast, European countries, have demonstrated a tendency towards reduced seroprevalence in pregnant women [36]. The relevant risk factors include lack of basic sanitation, inadequate eating and hygiene habits, contact with contaminated animals and soil, territoriality, climatic characteristics [7, 33, 37, 38], and the presence of more virulent strains of $T$. gondii [40]. The greatest concern during parasitic infection during pregnancy is the damage it can cause to the fetus [40]. Thus, atypical strains of T. gondii circulating in Brazil [41], may also be associated with severe cases of ocular toxoplasmosis [42] from congenital infection.

High rates of toxoplasmosis seroprevalence are expected in rural areas such as farms, due to the presence of domestic cats and the common presence of intermediate hosts, such as commensal rodents [43]. Despite the possibility of the infectious form spreading in these areas, the present study found no interference from the geographical location in the disease spread. The municipality where our study was conducted had surface and underground water collection points and water treatment. For historical and bureaucratic reasons, there was no treatment of water meters, making it impossible to control water consumption in this region [44]. Although this study did not present statistical significance in relation to basic sanitation, consumption of untreated water is considered a risk factor for the transmission of oocysts [45], mainly in developing countries.

One of the determining factors in the epidemiology of pathologies is the socioeconomic level [46]. According to Hotez (2008) [47], seroprevalence in the upper, middle, and lower socioeconomic strata in Brazil was $23 \%, 62 \%$, and $84 \%$, respectively. By combining sanitation and socioeconomic status, the prevalence rate in the adult population can reach $90 \%$ [48]. In 


\section{Conclusions}

the present study, more than a third of the pregnant women survived on up to a minimum wage; however, there was no significant difference in the serotype of $T$. gondii.

Consumption of undercooked/roasted meat is common in more than half of the group studied, whereas in the United Kingdom, pregnant women are warned about the consumption of unpasteurized milk and undercooked meat, and risk assessment for T. gondii infection is carried out individually during prenatal care [49]. In the study by Chandrasena et al. (2016) [50], with pregnant women in Sri Lanka, almost all women had the habit of washing their hands after handling raw meat. Although meat consumption is high, the meat is well cooked and prepared with traditional sauces, reducing the risk of parasite infection. In a study conducted in Western Iran, the prevalence of pregnant women infected with $T$. gondii was high among those who had consumed undercooked eggs and meat as well as unwashed vegetables [51].

In general, the diverse prevalence $(20-90 \%)$ of $T$. gondii infection can be understood by distinction between the populations studied, diagnostic methods, and specific risk factors that facilitate disease spread, including nutritional insecurity and/or contact with vector animals for T. gondii infection $[49,52,53]$. Finally, this study demonstrated that the high prevalence of $T$. gondii seropositivity in pregnant women may be related to multigravida, which should be considered a risk factor for toxoplasmosis.

Based on our data, we propose rigorous monitoring of pregnant women during prenatal care, in both primigravida and multigravida women, using screening tests, the provision of guidance to pregnant women on the risk factors for T. gondii infection. To target the relevant risk factors, it is essential to develop educational programs in communities together with preventive measures in the public health service that must be maintained, in addition to reinforcing the application of public health policies. 
249

250

251

252

253

254

255

256

257

258

259

260

261

262

263

264

265

266

267

268

269

270

271

272

\section{Ethical Approval and Consent to participate}

This study was approved by the Research Ethics Committee of the Universidade Federal de

Ouro Preto under the protocol CAAE: 23467219.7.0000.5150. All women were informed about the research, as well as read and assigned the consent to their participation.

\section{Consent for publication:}

All volunteers (women) of this research were informed and agreed to the publication of their anonymously data, as well as all authors read and agreed with the final version of this document.

\section{Availability of data and materials}

All data from this research, without identification of the participants, will be available under future request to the corresponding author.

\section{Conflict of interest}

The authors declare that the research was conducted without conflict of interest.

\section{Funding:}

AT (Process \# 305634/2017-8) and VFAN (Process \# 306036/2019-3) are grateful to the National Council for Scientific and Technological Development (CNPq) for the research productivity fellowship which supported the development of this research.

\section{Authors' contributions}


273 PVS (conceptualization, resource, writing-original draft preparation), DNMT (data curation,

274 resource), BAAM (data curation, resource), VFAN (conceptualization and data curation),

275 NSG (conceptualization, resource, writing-original draft preparation), AT (Supervision,

276 conceptualization, writing-reviewing and editing).

277

278 Acknowledgements. PVS, DNMT, BAAM and NSG thank Coordination of Improvement of

279 Higher Education Personnel (CAPES) and Minas Gerais Research Funding Foundation

280 (FAPEMIG) for their research scholarship. The authors also thank UFOP, and UFRN for

281 infrastructure support during this research.

282

283

Authors' information

284

PVS (priscilla.vilela@aluno.ufop.edu.br),DNMT (debora.toledo@aluno.ufop.edu.br),

285

BAAM (bianca.machado@aluno.ufop.edu.br), VFAN (aneto@cb.ufrn.br), NSG

286

(nasernizon@gmail.com), AT (talvani@ufop.edu.br).

287

288

References

289

1 Singh S. Mother-to-child transmission and diagnosis of Toxoplasma gondii infection

during pregnancy. Indian J Med Microbiol. 2003; 21:69-76.

291

292

2 Montoya JG, Liesenfeld O. Toxoplasmosis. Lancet. 2004; 363:1965-1976. doi:

293

10.1016/S0140-6736 (04)16412-X.

294

295

3 Montoya JG, Remington JS. Studies on the serodiagnosis of toxoplasmic lymphadenitis.

296

Clin Infect Dis. 1995;20(4):781-9. doi: 10.1093/clinids /20.4.781. 
304

305

306

307

308

309

310

311

312

313

314

315

316

317

4 Bossi P, Bricaire F. Severe acute disseminated toxoplasmosis. Lancet. 2004; 364:579. doi: 10.1016/S0140-6736(04)16841-4.

5 Ngô HM, Zhou Y, Lorenzi H, et al. Toxoplasma Modulates Signature Pathways of Human Epilepsy, Neurodegeneration \& Cancer. Sci Rep. 2017;13;7(1):11496. doi: 10.1038/s41598017-10675-6.

6 Carme B, Demar M, Ajzenberg D, Dardé ML. Severe acquired toxoplasmosis caused by wild cycle of Toxoplasma gondii, French Guiana. Emerg Infect Dis. 2009;15(4):656-8. doi: 10.3201/eid1504.081306.

7 Dubey JP, Lago EG, Gennari SM, Su C, Jones JL. Toxoplasmosis in humans and animals in Brazil: high prevalence, high burden of disease, and epidemiology. Parasitol. 2012; 139:1375-1424. doi: 10.1017 / S0031182012000765.

8 Afonso E, Germain E, Poulle ML, et al. Environmental determinants of spatial and temporal variations in the transmission of Toxoplasma gondii in its definitive hosts. Int $J$ Parasitol Parasites Wildl. 2013;23(2):278-85. doi: 10.1016/j.ijppaw.2013.09.006.
9
CDC.
Toxoplasmosis.
2018.
Disponível
em:

<https://www.cdc.gov/parasites/toxoplasmosis/epi.html >. Acesso em jan 2021.

10 Pappas G, Roussos N, Falagas ME. Toxoplasmosis snapshots: global status of Toxoplasma gondii seroprevalence and implications for pregnancy and congenital toxoplasmosis. Int J Parasitol. 2009; 39:1385-1394. 10.1016/j.ijpara.2009.04.003. 
32411 Flegr J, Prandota J, Sovicková M, Israili ZH. Toxoplasmosis - A Global Threat. Correlation of latent toxoplasmosis with specific disease burden in a Set of 88 countries. PLoS ONE. 2014;9(3):e90203. doi: 10.1371/journal.pone.0090203.

327

12 Baquero-Artigao F, Del Castillo M, Fuentes CI, et al. Guía de la Sociedad Española de

Infectología Pediátrica para el diagnóstico y tratamiento de la toxoplasmosis congénita.

13 Marques BA, Andrade GMQ, Neves SPF, Pereira FH, Talim MCT. Revisão sistemática

dos métodos sorológicos utilizados em gestantes nos programas de triagem diagnóstica pré-natal da toxoplasmose. Rev Med Minas Gerais. 2015;25(6):68-81. doi: 10.5935/22383182.20150099. 1999;353;1829-1833. doi: 10.1016/S0140-6736(98)08220-8. 10.1093/cid/cis234.

16 Prusa AR, Kasper DC, Pollak A, Gleiss A, Waldhoer T, Hayde M. The Austrian

Toxoplasmosis Register, 1992-2008. Clin. Infectar. Dis. 2015; 60:4-10. doi: 10.1093/cid/ciu724. 
17 Campbell OM, Graham WJ. Strategies for reducing maternal mortality: getting on with what works. Lancet. 2006;1284-1299. doi: 10.1016/S0140-6736(06)69381-1.

351

18 IBGE. Estimativas Projeções População. Disponível em:

<ftp://ftp.ibge.gov.br/Estimativas_Projecoes_Populacao/Revisao_2008_Projecoes_1980_205

0/Revisao_2008_Projecoes_1980_2050/>.Acesso em fev.de 2021.

355

19 Logar J, Petrovec M, Novak-Antolic Z, et al. Prevention of congenital toxoplasmosis in

Slovenia by serological screening of pregnant women. Scand. J. Infect. Dis. 2002; 34:201204. doi: $10.1080 / 00365540110080386$.

359

360

20 De Paschale M, Agrappi C, Manco MT, Cerulli T, Clerici P. Implementation of Screening for Toxoplasma gondii Infection in Pregnancy. J. Clin. Med. Res. 2010; 2:112-116. doi: 10.4021/jocmr2010.05.321w.

363

21 Peyron F, Mc Leod R, Ajzenberg D, et al. Congenital Toxoplasmosis in France and the United States: One Parasite, Two Diverging Approaches. PLoS Negl Trop Dis. 2017; 11;e0005222. doi: 10.1371/journal.pntd.0005222.

367

22 Wallon M, Peyron F. Congenital Toxoplasmosis: A Plos for a Neglected Disease. 369 Pathogens. 2018;23;7(1):25. doi:10.3390/pathogens7010025. 
37123 Wilking H, Thamm M, Stark K, Aebischer T, Seeber F. Prevalence, incidence estimations

372

and risk factors of Toxoplasma gondii infection in Germany: a representative, crosssectional, serological study. Scient Reports. 2016; 6:22551. doi: 10.1038/srep22551.

24 Benitez A do N, Gonçalves DD, Nino B de SL, Caldart ET, Freire RL, Navarro IT. Seroepidemiology of toxoplasmosis in humans and dogs from a small municipality in Parana, Brazil. Ciência Animal Bras. 2017; 18:1-9. doi: 10.1590/1089-6891v18e-42102.

25 Brasil. Ministério da Economia. Diário Oficial da União. Medida provisória número 919, de 30 de janeiro de 2020.

26 Carvalho GLX, Moreira LE, Pena JL, Marinho CC, Bahia MT, Machado-Coelho GLL. A comparative study of the TF-Test ${ }^{\circledR}$, Kato-Katz, HoffmanPons-Janer, Willis and Baermann-Moraes coprologic methods for the detection of human parasitosis. Mem Inst Oswaldo Cruz. 2012;107(1):80-4. doi: 10.1590/S0074-02762012000100011.

27 Stata Corp (2013) Stata Statistical Software: Release 13.0. College Station, TX: StataCorp LP.

28 Brasil. Secretaria Estadual de Saúde. Disponível em: <https://www.mg.gov.br/conteudo/conheca-minas/turismo/cidade-de-ouro-preto>. Acesso em fev 2021. 
29 IBGE. Esgotamento sanitário adequado: Ministério do Planejamento,

2010.

Disponível

em:

<https://cidades.ibge.gov.br/brasil/mg/ouro-preto/panorama>. Acesso em fev. de 2021.

397

30 DATASUS. Planilha Geral de Ouro Preto. 2002. Disponível em:

<http://tabnet.datasus.gov.br/tabdata/cadernos/mg.htm>. Acesso em dez. de 2020.

400

401

402

403

Gynecol. 2020;1-7. doi: 10.1080/01443615.2020.1789954.

404

405

406

407

408

409

410

411

412

413

414

415

416 10.15448/1983-652X.2017.2.23297.

417 
41835 Oliveira AC, Martins DOO, Silva EC, Botelho JAO. Prevalência de toxoplasmose em 419 gestantes triadas pelo programa estadual de proteção a gestantes de Mato Grosso Do Sul, no período de 2011. In: IV Seminário de Pesquisa e TCC da FUG, 2012. Trindade-GO: 421 Faculdade União de Goyazes. 2012; 81-102.

422

42336 Varella IS, Wagner MB, Darela AC, Nunes LM, Müller RW. Prevalence of seropositivity 424 for toxoplasmosis in pregnant women. J Pediatr. 2003;79(1):69-74. doi: 10.1590/s0021425 75572003000100012.

426

37 Schmidt DR, Hogh B, Andersen O, Fuchs J, Fledelius H, Petersen E. The national neonatal 428 screening programme for congenital toxoplasmosis in Denmark: results from the initial 429 four years, 1999-2002. Arch Dis Child. 2006;14(8):661-665. doi: 10.1136/adc.2004.066514.

430

38 Avelino MM, Campos Junior D, Parada JCB, Castro AM. Pregnancy as a risk factor to 432 acute toxoplasmosis seroconvertion. Eur J Obstet Gynecol Reprod Biol. 2003; 14:19-24. doi: 10.1016/S0301-2115(02)00353-6.

434

435

436

437

39 Avelino MM, Campos Junior D, Parada JB, Castro AM. Risk factors for Toxoplasma gondii infection in women of childbearing age. BJID. 2004;14(2):164-174. doi: 10.1590/S1413-86702004000200007.

438

439

40 Gilbert RE, Freeman K, Lago EG, et al. Ocular sequelae of congenital toxoplasmosis in 440 Brazil compared with Europe. PLoS Negl Trop Dis. 2008; 14:277. doi: 10.1371/journal.pntd.0000277. 
443

444

445

446

447

448

449

450

451

452

453

454

455

456

457

458

459

460

461

462

463

464

465

466

467

41 Avelino MM, Amaral WN, Rodrigues IM, et al. Congenital toxoplasmosis and prenatal care state programs. BMC Infect Dis. 2014; 14:33. doi: 10.1186/1471-2334-14-33.

42 Clementino Andrade MM, Pinheiro BV, Cunha MM, Carneiro ACAV, Andrade Neto VF, Vitor RWA. New gentotypes of Toxoplasma gondii obtained from farm animals in Northeast Brazil. Res Vet Sci. 2013;94(3):587-9. doi: 10.1016/j.rvsc.2013.01.006.

43 Mendes NH, Oliveira CB, Garcia CA, Holanda CM, Andrade-Neto VF. Epidemiological and serological profiles of ocular toxoplasmosis in the municipality of Natal, northeastern Brazil. Trans R Soc Trop Med Hyg. 2014;108(10):656-61. doi: 10.1093/trstmh/tru113.

44 Turner PB, Bateson DC. The Domestic Cat. The Biology of its Behaviour Cambridge University Press, Cambridge. 2000.

45 Prefeitura Municipal de Ouro Preto. Plano Municipal de Saneamento Básico. Ouro Preto, 2013. Disponível em: < http://cbhvelhas.org.br/plano-municipalde-saneamento-emouro-preto >. Acesso em jan 2021.

46 Bahia-Oliveira LMG, Jones JL, Azevedo-Silva J, Alves CC, Oréfice F, Addiss DG. Highly Endemic, Waterborne Toxoplasmosis in North Rio de Janeiro State, Brazil. Emerg Infect Dis. 2003; 9:55-62. doi: 10.3201/eid0901.020160.

47 Al-Malki ES. Toxoplasmosis: stages of the protozoan life cycle and risk assessment in humans and animals for an enhanced awareness and an improved socio-economic status. Saudi J Biol Sci. 2021; 28(1):962-969. doi: 10.1016/j.sjbs.2020.11.007. 
48 Hotez PJ. Neglected Infections of Poverty in the United States of America. PLoS Negl

49 Vaz RS, Rauli P, Mello RG, Cardoso MA. Toxoplasmose congênita: uma doença negligenciada? Política pública de saúde atual Brasileira. FACTS. 2011;(3):1-8.

474

Eur J Public Health. 2012; 23:648-52. doi: 10.1093/eurpub/cks075.

478

52 Ahmadpour GR, Ezatpour B, Hadighi R, et al. Seroepidemiology of Toxoplasma gondii infection in pregnant women in west Iran: determined by ELISA and PCR analysis. $J$ Parasit Dis. 2017;41(1):237-242. doi: 10.1007/s12639-016-0784-3.

53 Bóia MN, Carvalho-Costa FA, Sodré FC, Pinto GMT, Amendoeira MRR. Seroprevalence of Toxoplasma gondii infection among Indian people living in Iauareté, São Gabriel da Cachoeira, Amazonas, Brazil. Rev Inst Med Trop São Paulo. 2008; 50:17-20. doi: $10.1590 / \mathrm{s} 0036-46652008000100004$. 
49254 Amendoeira MRR, Coura LFC. A brief review of toxoplasmosis in pregnancy. Sci. Med. 493 2010;20(1):113-19. 
494 Table 1. Recommended weight gain according to pre-pregnancy maternal body mass index $495 \quad(\mathrm{BMI})$

\begin{tabular}{|cc|cc}
$\begin{array}{c}\text { Nutritional } \\
\text { status before } \\
\text { pregnancy }\end{array}$ & BMI $\left(\mathbf{k g} / \mathbf{m}^{2}\right)$ & $\begin{array}{c}\text { Weight gain during } \\
\text { pregnancy }(\mathbf{K g})\end{array}$ & $\begin{array}{c}\text { Weight gain per week in the } \\
\text { 2nd and 3rd trimester }(\mathbf{K g})\end{array}$ \\
\hline Underweight & $<18.5$ & $12.5-18$ & 0.5 \\
Eutrophic & $18.5-24.9$ & $11-16$ & 0.4 \\
Overweight & $25.0-29.9$ & $7-11.5$ & 0.3 \\
Obesity & $\geq 30.0$ & $5-9$ & 0.2 \\
\hline
\end{tabular}


497 Table 2 - Univariate analysis with the characterization of pregnant women evaluated in 2020,

498 Ouro Preto - MG, Brazil

\begin{tabular}{|c|c|c|c|c|c|}
\hline \multirow{2}{*}{ Variables } & \multirow[b]{2}{*}{$\mathbf{N}$} & \multirow[b]{2}{*}{$\%$} & \multicolumn{3}{|c|}{ Pregnant women } \\
\hline & & & $\begin{array}{l}\text { Uninfected } \\
(\mathbf{n}=71)\end{array}$ & $\begin{array}{l}\text { Infected by } \\
T . \text { gondii }(\mathrm{n}=60)\end{array}$ & $P$-value \\
\hline \multicolumn{6}{|l|}{ Socioeconomic variables } \\
\hline \multicolumn{6}{|l|}{ Age } \\
\hline Adolescents (<18 years) & 10 & 7.63 & 7 & 3 & \multirow{2}{*}{$0.343^{\&}$} \\
\hline Adults (>18 years) & 121 & 92.37 & 64 & 57 & \\
\hline \multicolumn{6}{|l|}{ Education } \\
\hline$<$ Complete high school & 55 & 41.98 & 28 & 27 & \multirow{2}{*}{$0.52 *$} \\
\hline$>$ Complete high school & 76 & 58.02 & 43 & 33 & \\
\hline \multicolumn{6}{|l|}{ Employment } \\
\hline Unemployed & 1 & 0.76 & 0 & 1 & $0.532^{\&}$ \\
\hline Employment bond & 61 & 43.56 & 29 & 32 & \# \\
\hline Student & 15 & 11.45 & 10 & 5 & $0.252^{\&}$ \\
\hline Housewife & 54 & 41.22 & 32 & 22 & $0.262^{\&}$ \\
\hline \multicolumn{6}{|l|}{ Income } \\
\hline Up to 1 minimum wage & 51 & 38.93 & 26 & 25 & $\#$ \\
\hline 1-2 minimum wage & 0 & 0 & 0 & 0 & NA \\
\hline 2-3 minimum wage & 69 & 52.67 & 38 & 31 & $0.657^{\&}$ \\
\hline >4 minimum wage & 11 & 8.4 & 7 & 4 & $0.519^{\&}$ \\
\hline \multicolumn{6}{|l|}{ Habitation } \\
\hline City & 79 & 60.31 & 47 & 32 & \multirow{2}{*}{$0.134 *$} \\
\hline District & 52 & 39.69 & 24 & 28 & \\
\hline \multicolumn{6}{|l|}{ Environmental variables } \\
\hline \multicolumn{6}{|l|}{ Access to treated water } \\
\hline No & 18 & 13.74 & 8 & 10 & \multirow{2}{*}{$0.371 *$} \\
\hline Yes & 113 & 86.26 & 63 & 50 & \\
\hline \multicolumn{6}{|l|}{ Access to sewer services } \\
\hline No & 14 & 10.69 & 7 & 7 & \multirow{2}{*}{$0.739 *$} \\
\hline Yes & 117 & 89.31 & 64 & 53 & \\
\hline \multicolumn{6}{|l|}{ Contact with pets } \\
\hline Yes & 66 & 50.38 & 31 & 35 & $\#$ \\
\hline $\begin{array}{l}\text { Pet in the house (but without direct } \\
\text { contact) }\end{array}$ & 22 & 16.79 & 12 & 10 & $0.538^{\$}$ \\
\hline No & 43 & 32.82 & 28 & 15 & $0.407^{\$}$ \\
\hline \multicolumn{6}{|c|}{ Animal waste disposed of in the house } \\
\hline No & 64 & 48.85 & 39 & 25 & \multirow{2}{*}{$0.130^{*}$} \\
\hline Yes & 67 & 51.15 & 32 & 35 & \\
\hline \multicolumn{6}{|l|}{ Gestational variables } \\
\hline \multicolumn{6}{|l|}{ Gestational age } \\
\hline First trimester & 37 & 28.24 & 23 & 14 & \# \\
\hline Second trimester & 49 & 37.40 & 24 & 25 & $0.224^{\$}$ \\
\hline Third trimester & 45 & 34.35 & 24 & 21 & $0.421^{\$}$ \\
\hline Pregnancy & & & & & \\
\hline
\end{tabular}


Primigravida

$53 \quad 40.46 \quad 36$

17

$0.009 *$

Multigravida

$\begin{array}{ll}78 & 59.54\end{array}$

35

43

Neuro-ocular complications in the

firstborn

Yes

No

123

93.89

2

69

6

54

$0.142^{\&}$

Pre-gestational BMI

Not Overweight

$\begin{array}{lll}55 & 41.98 & 34\end{array}$

21

Overwight

$76 \quad 58.02$

37

39

$0.136^{*}$

Gestational weight gain

Eutrophic

Low

$43 \quad 35.11$

24

22

$44 \quad 33.59$

27

17

$\begin{array}{lll}41 & 31.30 \quad 20\end{array}$

21

Clinical variables

Parasitological examination of stools $(\mathrm{N}=78)$

Negative

$\begin{array}{lll}67 & 85.90 & 40\end{array}$

27

$0.056^{\&}$

Positive

$11 \quad 14.10$

3

8

Blood pressure

Normotensive

Hypertensive

$115 \quad 89.84$

61

54

$5 \quad 3.91$

1

4

$0.148^{\$}$

Hypotensive

$8 \quad 6.25$

8

0

NA

\section{Dietary variables}

Handwashing before food preparation

No

$7 \quad 5.34$

12494.66

6

1

$0.124^{\&}$

Yes

65

59

Footnote: *Pearson's Chi-square test ${ }^{\$}$ Chi-square partition test ${ }^{\circledR}$ Fisher's exact test. \# Reference class 
Table 3 - Multivariate analysis: Risk or protection factors associated with $T$. gondii infection in pregnant women evaluated in 2020 at Ouro Preto, MG, Brazil.

\begin{tabular}{|c|c|c|c|c|}
\hline \multirow[t]{2}{*}{ Variables } & \multicolumn{4}{|c|}{ T. gondii-infected pregnant women variables } \\
\hline & $\begin{array}{c}\text { OR } \\
(\text { IC } 95 \%)\end{array}$ & P-value & $\begin{array}{c}\text { ORa } \\
(\text { IC 95\%) }\end{array}$ & P-value \\
\hline \multicolumn{5}{|l|}{ Social variables } \\
\hline \multicolumn{5}{|l|}{ Habitation } \\
\hline City & 1 & 0.704 & 1 & 0.685 \\
\hline District & $0.78(0.23-2.70)$ & & $0.77(0.22-2.70)$ & \\
\hline \multicolumn{5}{|l|}{ Environmental variables } \\
\hline \multicolumn{5}{|l|}{$\begin{array}{l}\text { Animal waste disposed } \\
\text { of in the house }\end{array}$} \\
\hline No & 1 & 0.552 & 1 & 0.566 \\
\hline Yes & $0.72(0.24-2.12)$ & & $0.73(0.25-2.15)$ & \\
\hline \multicolumn{5}{|l|}{ Gestational variables } \\
\hline \multicolumn{5}{|l|}{ Pregnancy } \\
\hline Primigravida (child-free) & 1 & 0.010 & 1 & $0.018 *$ \\
\hline Multigravida & $2.60(1.25-5.39)$ & & $2.50(1.17-5.36)$ & \\
\hline \multicolumn{5}{|l|}{ Children complications } \\
\hline No & 1 & 0.664 & 1 & 0.664 \\
\hline Yes & $1.74(0.14-21.53)$ & & $1.74(0.14-21.53)$ & \\
\hline \multicolumn{5}{|l|}{ Pre-gestational BMI } \\
\hline Without overweight & 1 & & 1 & 0.397 \\
\hline With overweight & $0.62(0.20-1.92)$ & 0.408 & $0.60(0.18-1.95)$ & \\
\hline \multicolumn{5}{|l|}{ Clinical variables } \\
\hline \multicolumn{5}{|l|}{$\begin{array}{l}\text { Parasitic examination in } \\
\text { stools }(\mathrm{N}=78)\end{array}$} \\
\hline Negative & 1 & 0.370 & 1 & 0.366 \\
\hline Positive & $2.45(0.34-17.38)$ & & $2.47(0.35-17.6)$ & \\
\hline \multicolumn{5}{|l|}{ Blood pressure } \\
\hline No & 1 & 0.183 & 1 & 0.203 \\
\hline Yes & $4.51(0.49-41.67)$ & & $4.23(0.45-39.17)$ & \\
\hline \multicolumn{5}{|l|}{ Dietary variables } \\
\hline \multicolumn{5}{|c|}{ Handwashing before food preparation } \\
\hline No & $0.74(0.05-11.25)$ & 0.827 & $0.75(0.05-11.54)$ & 0.838 \\
\hline Yes & 1 & & 1 & \\
\hline
\end{tabular}

